\title{
ラット精細管の電顕的細胞化学的研究：発育段階に拈ける
}

\author{
ホスファターゼ局在の変化 \\ 東京大学医学部泌尿器科教室（主任：新島端夫教授） \\ 石田仁男

\section{AN ULTRACYTOCHEMICAL STUDY ON PHOSPHATASE ACTIVITIES IN RAT SEMINIFEROUS TUBULES DURING POSTNATAL DEVELOPMENT}

\author{
Yoshio Ishida \\ Department of Urology, Faculty of Medicine, The University of Tokyo \\ (Director: Prof. T. Niijima)
}

An ultracytochemical study was performed, for the first time, in the rat seminiferous tubules during postnatal development. Differentiation of the spermatogenic and Sertoli cells and changes of phosphatase localizations were studied.

The seminiferous tubules were obtained from the rats of Wistar strain at 1,2,3,4 and 5weeks and adult age. Rats in a litter mates were also used for the study of the changes during 12 to 18days after birth. The enzymes studied were acid phosphatase (ACPase) according to Gomori's method and adenosine triphosphatase (ATPase) by the method of Wachstein and Meisel.

ACPase activity was found in the Golgi apparatuses and lysosomes of all spermatogenic cells in all ages of rats. The activity was also positive in the Golgi apparatuses and lysosomes of both immature and mature Sertoli cells. Spermatids began to appear 4 weeks after birth and maturation was completed by 5 weeks. Acrosome vesicles and acrosomes at the beginning of cap formation in the early spermatids was ACPase positive, while ACPase activity disappeared in the acrosomal cap as the spermatids matured. The vesicles in the residual bodies of spermatids showed a positive reaction. ACPase activity in the acrosomes of mid and late spermatids might be masked cytochemically by unknown mechanisms until fertilization.

ATPase activity was negative in both spermatogenic cells and Sertoli cells until 13 days after birth under various conditions of fixation and incubation. In 13days old rats, ATPase activity started to appear in the Golgi apparatuses of spermatogonia and intercellular spaces (ICS) between Sertoli cells facing each other. In 16days old rats, the activity became positive in the ICS between Sertoli cells and spermatogenic cells. Gradual increase of the enzyme activity was observed as the rat grew. At the age of 18days, ATPase activity became stronger but the localization was similar. The time course of ATPase activity in seminiferous tubules was coupled with Sertoli cell differentiation forming tight junctions and spermatocyte development. In adult rats, the activity was found in the Golgi apparatuses of both Sertoli cells and spermatogenic cells as well as in the ICS between Sertoli cells facing each other and in those between Sertoli cells and spermatogenic cells. ATPase activity, however, was negative in the ICS where the spermatogenic cells were facing each other. The present study for the first time described the changes of phosphatase activities during the postnatal development of rat seminiferous tubules. The time course and the distribution of ATPase activity during postnatal testicular development suggest that the enzyme may play some role in metabolic transport between Sertoli cells and developing spermatogenic cells.

要旨：ラット精細管の生後発育を電顕的酵素細胞化学的に研究した。各発育段階のウィスター系ラット 精巣を用い，酸性ホスファターゼ（ACPase, Gomori 法）とアデノシントリホスファターゼ（ATPase， Wachstein and Meisel 法)の局在を調べた. 経日的観察には同腹ラットを用いた. ACPase 活性は生後 1 週から精細胞およびセルトリ細胞のゴルジ装置とライソン゙ームに認められ，成熟ラットに至るまで活 
性の強さに差はあれ局在部位は同一であった。早期精子細胞の前先体顆粒, 初期の先体内には ACPase 活性が陽性であるが, acrosomal cap 形成以後では活性は消失した。. ATPase 活性は生後13日に初めて 出現し, 日を追って増強し18日齢では精細管全域に活性を認めた。局在部位は精細胞とセルトリ細胞の ゴルジ装置および両細胞系の形質膜外側であった. ATPase 活性の出現時期はセルトリ細胞の分化にと もなら密着結合の形成および精母細胞の出現時期と一致した. 形質膜における ATPase 活性の局在はセ ルトリ細胞同士および精細胞とセルトリ細胞とが接する部分（細胞間隙）であり，精細胞同士の接する 間吵には活性を認めなかった。本研究は精細管の生後発育におけるホスファターゼ活性の出現と局在を 初めて明らかにしたもので, 活性出現時期とその分布からセルトリ細胞が精細胞の分化に関与し, 特に 代謝移送と関連することが示唆された。

\section{緒 言}

精細管上皮は精細胞とセルトリ細胞からなり，これ らが精細管内に複雑に層状配列している。精細胞は幹 細胞より分化し精祖, 精母細胞（第一次, 第二次）を 経て精子細胞となる。この精子形成過程に执ける細胞 の形態変化は著しくかつ特徵的である ${ }^{1)}$ 。これに関す る組織学的 ${ }^{2)}$, 細胞動態学的 ${ }^{3)}$, 電顕的報告 ${ }^{4)}$ は多い. ラット精巣の発育をみると胎生期から存在する原始生 殖細胞（gonocyte）は生後 4 日頃より体細胞分裂が盛 んになり, 生後 9 日には精祖細胞に分化し，15日頃に 第一次精母細胞 (primary spermatocyte) が出現する. 減数分裂を行い第二次精母細胞 (secondary spermatocyte)を経て26日に最初の精子細胞が出現する2). 早期精子細胞（early spermatid）においてゴルジ装置 の小胞内に前先体顆粒 (proacrosomal granule) が出 現する。顆粒は融合してゴルジ震とともに核の前端に 密着する。その後ゴルジ囊は核を包むようになり頭帽 となる．その中の顆粒が先体 (acrosome) である5). ゴルジ装置は先体が形成されると尾部の細胞質に移動 し，のちに細胞小滴の中に見い出される，先体からは なれたゴルジ装置はゴルジ遺残体 (residual body) と 呼ばれる ${ }^{6}$. 精細胞の分裂は成熟し'た精細管内では整 然と波状的に進行しており，各分化段階の細胞は精細 管の中でそれぞれの細胞群を形成して打り動物種によ り各分化段階での所要時間や周期は一定している3 ${ }^{3)}$.

一方セルトリ細胞は支持細胞とよばれ精細胞の間に複 雑な細胞質突起を出して存在し精子発生を円滑にする ための種々の特殊な機能を果たすと考学られている. セルトリ細胞は胎生期には未熟型で占められ生後も未 熟型の増殖が続く．生後15日頃に細胞は分化し成熟型 が出現する ${ }^{277}$. セルトリ細胞の分化にともない細胞間 には特殊な密着結合が形成される。この細胞間接着装 置はランタンの浸透を阻止し，一つの関門として機能 する。これが血液一精巣関門(blood-testis barrier) ${ }^{8) 9}$
として働くと考号られており，その完成は生後16２0 日と報告されている10).な拈七トでは11１3歳といわ れている ${ }^{11}$. 成熟精巣の電顕的酵素細胞化学的研究は 1963年 Tice and Barrnett ${ }^{12)}$ によりスファターゼに つき初めて行われた。その後各種動物に扣いて精子形 成とホスファターゼ局在との関連が検索され, 細胞化 学的に形質膜の機能分化が示され, 精子形成とゴルジ 装置の機能状態との関連も明らかにされてきた ${ }^{13)}$ 。一 方精巣の発育段階の研究は電顕的形態観察にとどまっ て招り7)14), 細胞化学的報告は未だなされていない. 本 研究はラット精巣の生後発育過程に怙けるホスファ ターゼ局在を初めて明らかにしたものである。さらに 酵素活性の出現時期, 局在部位の変化と発育に拈ける 構造変化とに一定の関連を認めたのでここに報告す る.

\section{1）動物実験}

生後 1，2，3，4，5週执よび性的成熟した雄性 ウィスター系ラット(各群 $10,9,11,6,9 ， 11 匹)$ を用いた。ラットは日本生物材料センターより購入し た。細胞分化のはげしい時期，すなわち生後12ないし

表 1 Experiments using litters of rats

\begin{tabular}{c|c|c|c|c|c|c|c|c}
\hline \multirow{2}{*}{ Exp. } & \multirow{2}{*}{$\begin{array}{c}\text { No. of } \\
\text { animal }\end{array}$} & \multicolumn{7}{|c}{ postnatal days } \\
\cline { 3 - 9 } & & 12 & 13 & 14 & 15 & 16 & 17 & 18 \\
\hline A & 3 & 1 & - & - & 1 & - & - & 1 \\
B & 5 & 1 & 1 & 1 & 1 & 1 & - & - \\
C & 4 & 1 & 1 & 1 & 1 & - & - & - \\
D & 4 & - & - & 1 & 1 & 1 & 1 & - \\
E & 5 & - & 1 & 1 & 1 & 1 & 1 & - \\
F & 3 & - & - & - & 1 & 1 & - & 1 \\
G & 5 & - & - & 1 & 1 & 1 & 1 & 1 \\
H & 5 & - & - & 1 & 1 & 1 & 1 & 1 \\
I & 4 & 1 & 1 & 1 & 1 & - & - & - \\
\hline
\end{tabular}

(- : Experiment not performed) 
18日の観察には一腹のラットを用いた。経日的観察の 実際は表 1 に示した。

ラットにネンブタールを腹腔内投与し麻酔下に開腹 し, 精巣を摘出し直ちに精巣白膜を切開し精細管を取 り出した。

\section{2）電顕標本の作製（形態観察）}

精細管をカミンリで細切し, 冷 $2 \%$ グルタールアル デヒド（GLA）液（0.1M カコジル酸緩衝液 $\mathrm{pH} 7.2$,

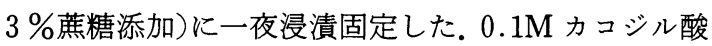
緩衝液（pH 7.2）にて洗滌し冷 $1 \%$ オスミウム酸溶液 にて 90 分間固定し，上昇エタノール系列で脱水し，プ ロピレンオキサイドで置換した後エポン $812 に$ 包埋し た.

\section{3）酵素細胞化学}

酸性ホスファターゼ（acid phosphatase, ACPase; E.C. 3.1.3.2）活性の検出は $\beta$-グリセロリン酸（第一化 学）を基質とし $\mathrm{pH} 5.0 て ゙$ Gomori 法（1952) ${ }^{15}$ によっ た。 アデノシントリホスファターゼ (adenosine triphosphatase, ATPase : E.C. 3.6.1.3）活性の検出はア デノシン 5'トリホスフェート(Sigma)を基質とし $\mathrm{pH}$ 7.0で Wachstein and Meisel 法 (1957) ${ }^{16)}$ とり行っ た.

酵素細胞化学用には細切した精細管を冷 $2 \%$ GLA （ $3 \%$ 蔗糖添加）溶液中にて浸漬し前固定し， $0.1 \mathrm{M}$ 力 コジル酸緩衝液で 3 回洗滌した後, 厚さ約 $40 \mu \mathrm{m}$ の凍 結切片を作製した。切片を再度洗滌した後, 酵素反応 液中に $37^{\circ} \mathrm{C} て ゙$ 浸漬した。固定括よび浸漬条件は予備実 験により決定した。すなわち ACPase では固定60分 間, 浸漬15分間であり ATPase では固定30分間, 浸漬 15分間であった。浸漬終了後, 切片は冷 $1 \%$ オスウ ム酸溶液にて45分間の後固定を施し, エタノール脱水 を経てェポンに包埋した。 浸漬終了後の切片の一部は 水洗後 $1 \%$ 硫化アンモニウム液にて 2 分間発色した。 洗滌後グリセリン封入を行い光学顕徽鏡的観察に供し た. 対照実験として $40 \mu \mathrm{m}$ 切片を基質を抜いた反応液 (substrate free medium) 中にて浸漬した. ACPase に 対しては弗化ソーダを最終濃度 $10 \mathrm{mM}$ となるよう反 応液に添加し阻害実験も行った。

\section{4) 電顕的観察}

LKB4801型超ミクロトームを用いて超薄切片を作 製した。形態観察用超薄切片には酢酸ウランおよびク エン酸鉛の二重電子染色を, 細胞化学用切片にはクエ ン酸鉛単染色を施し, JEM $100 \mathrm{C}$ 型透過型電子顕微鏡 (80KV) 下で観察した。

\section{1. 形態観察}

結 果

生後 1 週までのラット精細管は原始生殖細胞と未熟 型セルトリ細胞によって占められていた。その原始生 殖細胞は体細胞分裂をくり返し生後 2 週にはほとんど みられなくなり, 精祖細胞つづいて精母細胞が出現し 始めた. 生後 4 週になると早期精子細胞が出現し，以 後日を追うにしたがい精子細胞の成熟が観察された。 生後 2 週未満の精細管内のセルトリ細胞は全て未熟型 であった。 その後細胞質突起の出現, 核の多形化, 細 胞間接着装置の形成などセルトリ細胞の分化が進み生 後 3 週では精細管内のセルトリ細胞は全て分化し成熟 型となった。

\section{ACPase 活性の局在}

生後 1 週では原始生殖細胞抒よび未熟型セルトリ細 胞のゴルジ装置とライソン゙ームに酵素活性を認めた (Fig. 1). 生後 2 週では新たに出現した精祖細胞およ び未熟型セルトリ細胞のゴルジ装置とライソゾームに 活性がみられた (Fig. 2). 生後 3 週になると精母細胞 および成熟型セルトリ細胞が出現し，それらのゴルジ 装置とライソゾームにも活性を認めた。生後 4 週では 出現し始めた精子細胞内のゴルジ装置とライソン゙ーム に加兄形成初期の先体に活性を認めた (Fig. 3，4). ᄂ かし精子細胞の成熟段階が進み中期および後期精子細 胞では頭帽内における ACPase 活性は認められなく なった（Fig． 5)。この所見は成熟ラット精巣に打いて も確認された。即ち同一切片の観察で早期精子細胞内 の先体には活性を認めた（Fig. 6)。乙かし中期と後期 の精子細胞に打いて頭帽形成が進み，頭帽が完成した ものには, ACPase 活性を認めなかった. 精細胞のゴル ジ装置とライソゾームには生後 1 週から成熟に至るま で全てに活性がみられた、ゴルジ装置における反应 物の沈着は精細胞では trans 側の層板，小胞に認めら れた (Fig. 6)。セルトリ細胞では trans 側に活性を認 めるものが多いが全体に認めるものもあり一定ではな かった，精子細胞の成熟過程で先体形成が進みゴルジ 装置が先体をはなれ尾部の細胞質に移動している時期 ではゴルジ装置にはまだ活性が認められた (Fig. 7). ACPase 活性は後期精子細胞の遺残体中の小胞にも活 性を認めた（Fig. 8)。対照実験として酵素基質を抜い た浸漬液拈よび阻害剤（NaF，10mM）を加光た浸漬 液中で各試料の反応を行った。いずれの標本に招いて も反応産物を認めなかった。

3. ATPase 活性の局在 
生後 12 日以前の精細管上皮には種々の条件を設定し たにもかかわらず酵素活性を認めなかった，酵素活性 が初めて認められたのは日齢13日のラット精巣でその 局在は精祖細胞のゴルジ装置およびセルトリ細胞同士 の細胞間吵であった (Fig. 9). 反応は弱いが活性は確 実に認められた。14日齢ではセルトリ細胞同士の細胞 間吵（Fig. 10）のみならず，七ルトリ細胞のゴルジ装 置 (Fig. 11) にも活性を認めた。16日齢では新たに出 現した精母細胞のゴルジ装置およびセルトリ細胞と精 祖, 精母細胞との細胞間隙にも活性を認めるにいたっ た(Fig. 12).この反応は徐々に増強し生後18日では酵 素活性はさらに明瞭となり成熟例と同様な所見を認め るに至った。成熟ラットでは精細胞，セルトリ細胞と もゴルジ装置に活性が認められた。さらに全ての精細 胞（精祖, 精母, 精子細胞）とセルトリ細胞との細胞 間隙，セルトリ細胞同士の細胞間吵に活性を認めた (Figs. 13，14）. しかし幼若㧍よび成熟精巣とも精細胞 同士が相接する細胞間吵には酵素活性を認めなかった (Figs. 12，14 arrow head).な抢反応産物の沈着は形 質膜では膜の外側に存在し，ゴルジ装置ではゴルジ槽 と小胞の内部に存在した。 しかし cis 側, trans 側に対 する規則性は認められなかった。酵素基質を抜いた溶 液中で浸漬を行った精細管内には各日齢とも反応産物 は認められなかった。

\section{考 察}

精細管上皮は精細胞とセルトリ細胞からなり層状に 配列している．精細胞は精子に至る過程で著明な形態 的变化を起こし，これに関して数多くの報告があ る $^{3) 5)}$ ．セルトリ細胞は精子形成を円滑にするための 種々の特殊な機能を果たすと考えられている17).
成熟精巣におけるホスファターゼの局在は1963年 Tice and Barrnet $\mathrm{t}^{12)}$ によりラットにおいて初めて報

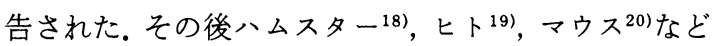
に执いての報告がなされた. 1961年 Novikoff ${ }^{21}$ およよ゙ Allen"2)がホスファターゼ活性を細胞化学的に検出す る方法を報告し thiamine pyrophosphatase (TPPase), nucleoside diphosphatase (NDPase) が ゴルジ装置に局在することを指摘した。その後の研究 からゴルジ装置に局在する酵素として ACPase, ATPase, alkaline phosphatase (ALPase) が知られ るにいたり，これらの酵素をマーカーとしてゴルジ装 置の消長を追跡することが可能となった ${ }^{12223)}$. 本研究 において成熟ラットの ACPase 活性の局在は Ticeら の報告 ${ }^{12)}$ と基本的に一致していた。若干の相違点は Tice らはセルトリ細胞のゴルジ装置には ACPase 活 性は認めなかったと記載しているが本研究では明らか に反応陽性であった。 また他の報告例 ${ }^{13)}$ でも陽性とさ れている。また Barham ら ${ }^{19}$ はヒトに関して精細胞の ゴルジ装置と先体には活性がなかったとしている点が ラットでの本研究と相違していた。精子形成過程では Tice ら ${ }^{12)}$ がラット精子細胞でTPPase, ACPase, NDPase，NTPase 活性を検出しゴルジ装置における 活性を指標として先体がゴルジ装置の変形により形成 されてくることを観察した。 その後ラット精子細胞に 関しての報告 ${ }^{24)}$ るえている.ゴルジ遺残体中の小胞 には本研究に扣いても報告と同様に ACPase 活性を 弱いながら認めたが，この時期には先体に活性はな かった．先体はゴルジ装置由来の膜によってつつまれ た一種の蛋白性分泌顆粒と同等のものと考兄られてお り PAS 反応陽性を呈し多糖類のほか多数の加水分解

Fig. 1 8 ACPase cytochemistry in developing rat testis.

Fig. 1 1week old. Reaction products are found in the Golgi apparatus of a gonocyte. $\times 33,000$

Fig. 2 2weeks old. Reaction products are localized in the Golgi apparatus of immature Sertoli cell. $\times 10,000$

Fig. 3 4weeks old. The acrosome (arrow) at the beginning of cap formation as well as Golgi apparatus are ACPase positive. $\times 19,000$

Fig. 4 4weeks old. Reactive sites for ACPase are in the Golgi apparatus and lysosomes of the mature Sertoli cell. $\times 4,000$

Fig. 5 4weeks old. ACPase activity disappears in the acrosome (arrow) as the cap formation progressed in the mid spermatid, while the activity is positive in the Golgi apparatus. $\times 14,000$

Fig. 6 Adult. Reaction products are found in the Golgi apparatus and acrosomal granule (long arrow) and lysosomes (short arrow) of the early spermatid. $\times 6,000$

Fig. 7 Adult. ACPase was positive in the residual Golgi apparatus of late spermatid. $\times 18,000$

Fig. 8 Adult. Reaction products are found in the vesicles of the residual body (arrow) of the late spermatid. $\times$ 11,000 

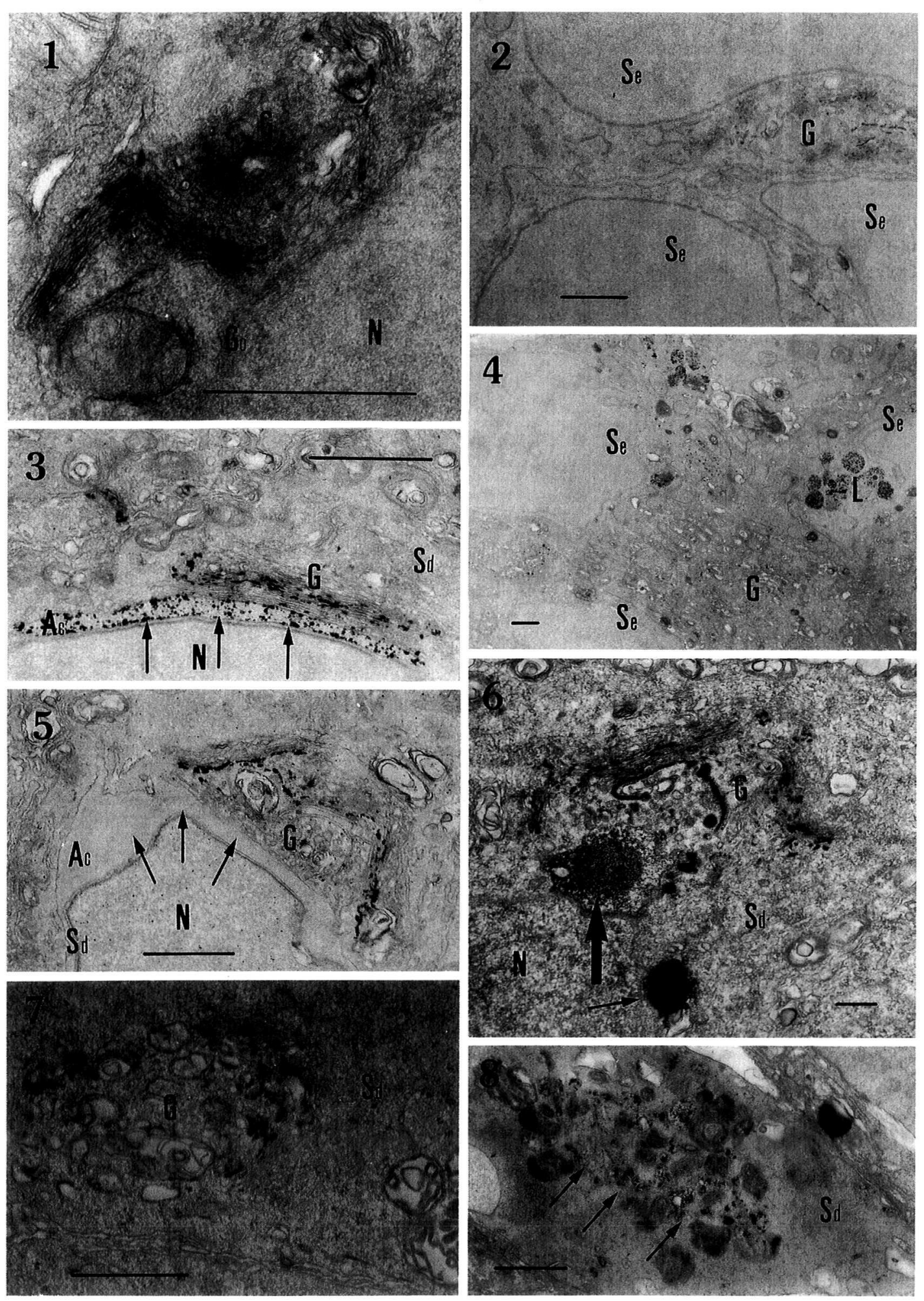

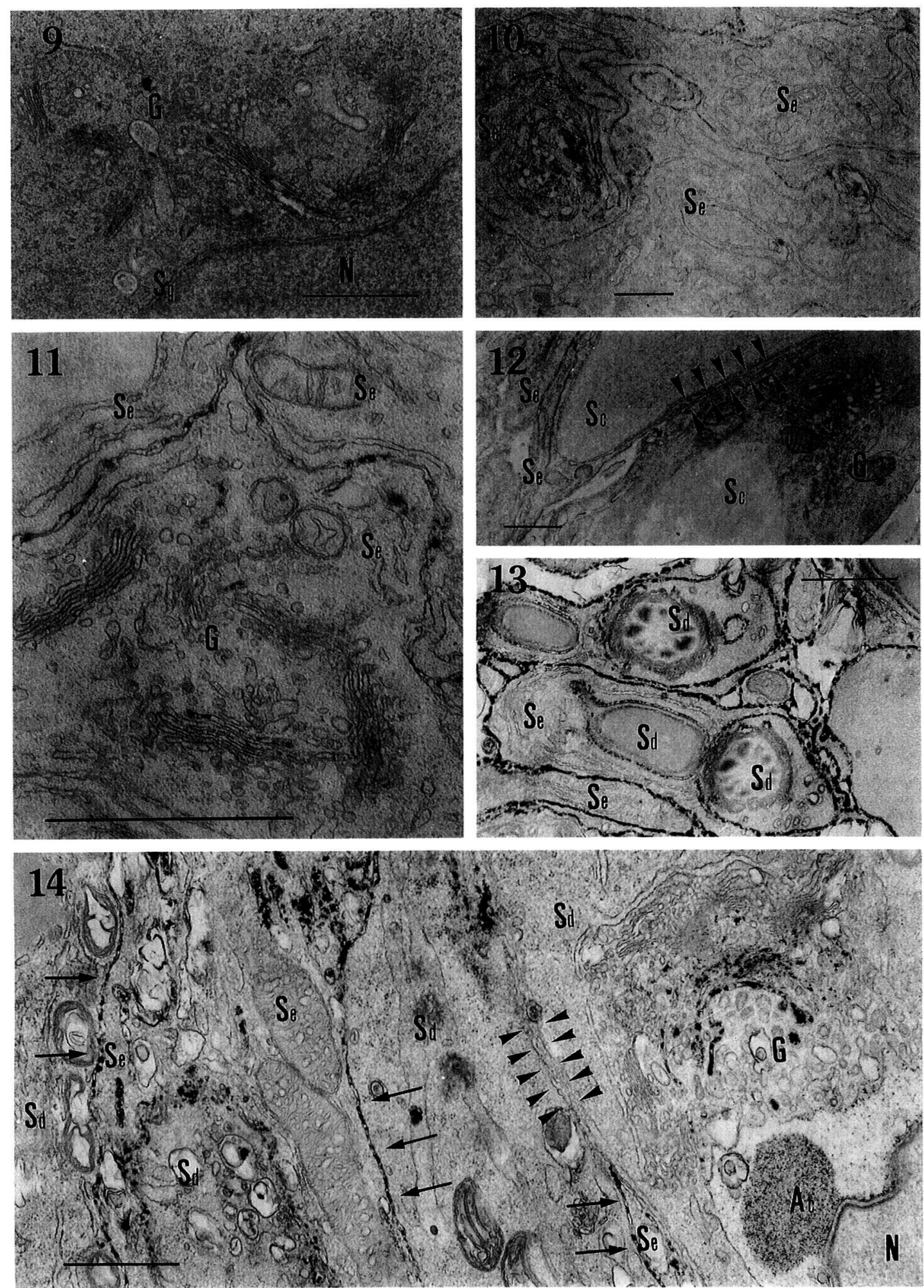
Fig. 15 Schematic representation of positive sites for ACPase and ATPase in seminiferous tubules of 18 days old rat.

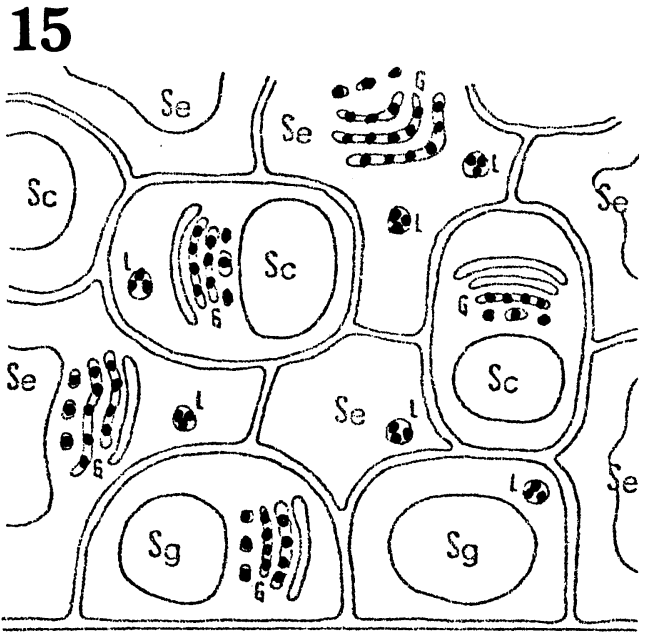

ACPase

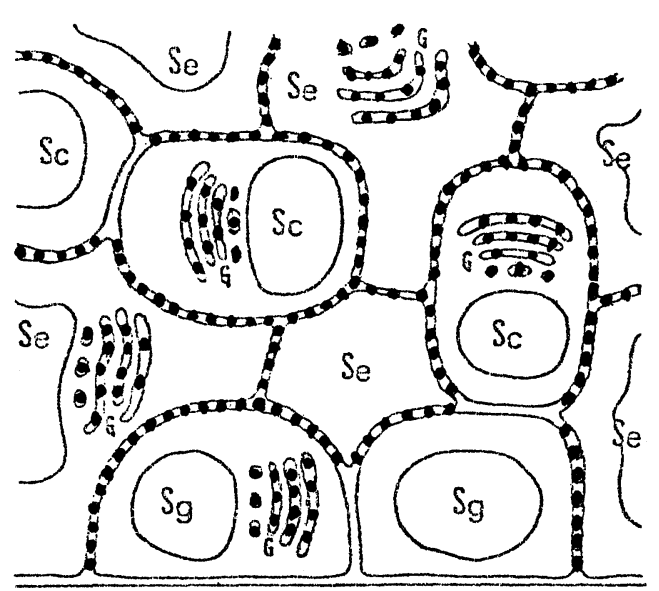

ATPase

(Go denotes gonocyte, Sc: spermatocyte, Sd: spermatid, Se: Sertoli cell, Sg: spermatogonium, Ac: acrosome, G: Golgi apparatus, L : lysosome, $\mathrm{N}$ : nucleus, respectively) (Scales in the figures indicate one micron.)

酵素を含んでいる。これらプロテアーゼ，ヒアルロニ ダーゼ, 酸性ホスファターゼや他の水解酵素は先体が 受精過程で卵丘細胞群や卵子透明帯への通過時に重要 な役割をはたしていることが知られている25). ACPase が精子細胞の先体形成初期の先体に活性を呈 している事を考えると，先体形成中期以後受精まで何 らかの機序にて，この活性が和さえられていると考え られる.この機序に関してはさらに検討が必要と思わ れる。
成熟ラットではATPase 活性が精細胞とセルトリ 細胞との細胞間吵に認められる事はすでに報告されて

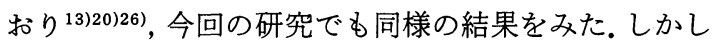
ATPase 活性が発育段階のいつ頃から出現するかに ついては今だ報告をみない。その出現時期は各個の ラットを用いた実験で生後 2 週前後であった。生下時 間の同定に幅があるので，時期および活性発現の経日 的変化を正確に追究すべく同腹ラットを用いた実験を 行った.すなわち同腹のラットを用い生後 $12,13,14$,

Figs. 9 14 ATPase cytochemistry in developing rat testis.

Fig. 9 13days old. Reaction products can be seen in the Golgi apparatus of the spermatogonium. $\times 18,000$

Fig. 10 14days old. Reaction products are observed in the intercellular spaces (ICS) between Sertoli cells facing each other. $\times 9,000$

Fig. 11 14days old. Reaction products are found in the Golgi apparatus of Sertoli cell and the ICS between Sertoli cells facing each other. $\times 39,000$

Fig. 12 16days old. Reaction products are found in the Golgi apparatus of the spermatocyte and in the ICS between Sertoli cells facing each other and in the spaces between Sertoli cell and the spermatocyte. No reaction is observed in the ICS between spermatocyte facing each other (arrow head). $\times 9,000$

Fig. 13 Adult. Reaction products are found in the ICS between the spermatid and Sertoli cell. The spaces between Sertoli cells facing each other also are positive. $\times 15,000$

Fig. 14 Adult. Reaction products localize in the Golgi apparatus of spermatid and in the ICS between Sertoli cells facing each other and in spaces between Sertoli cell and the spermatid (arrow). No reaction is observed in the ICS between spermatids facing each other (arrow head). $\times 18,000$ 
15，16，17，18日の時期に分布するよう実験を計画し た（表 1 ）。その結果 1 日前後のずれがみられる事も あったが13日には ATPase の活性が弱いながら認め られ始め，16日には成熟ラットと活性の出現部位はほ ぼ同様となった。この活性の出現時期は精母細胞の出 現時期 2 およ び血液一精巣関門が完成するといわれて

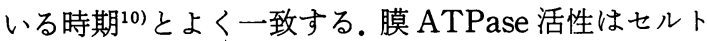

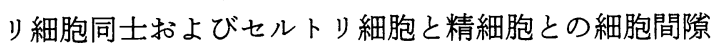
の細胞膜に反応陽性で, 精細胞同士の細胞間隙の細胞 膜には反応陰性であった。これは成熟ラット ${ }^{12)}$, マウ $ス^{20)}$ ， 八ムスター ${ }^{18226)}$ の報告と一致し，成熟マウスでの adenylate cyclase ${ }^{27)}$ の分布ともよく類似していた。し かし Barhamのヒトでの所見 ${ }^{19)}$ とは精祖一精祖細胞 の接点で反応を認め，七ルトリ細胞同士の細胞間隙に は反応をほとんど認めなかったとしている点で本研究 と相違をみた。

セルトリ細胞は生後15日頃より成熟型への分化が始 まるとされる277)．胎生期には Müller 管に対する抑制 物質である糖蛋白 ${ }^{28)}$ を分泌し, 成熟化が始まり血液 一精巣関門が完成する直前にはアンドロゲン結合蛋白 (androgen binding protein; ABP) ${ }^{10)}$ 産生分泌し始 める。セルトリ細胞間の密着結合により精細管は $2 つ$ の生理的部分すなわち basal compartment と adluminal compartmentに分けられる29). basal compartment は基底膜と密着結合との間の部分で, ここに は精祖細胞が存在する. adluminal compartment は密 着結合から管腔までの部分で精祖細胞から分裂増殖し た精母細胞, 精子細胞を含む. セルトリ細胞はこの 2 つの compartmentにまたがって存在する. basal compartment では血液から浸透してきた物質と基底 膜で直接接触できるが adluminal compartment では 血液一精巣関門によりそれらの物質と精細胞とは直接 接触でさない環境となる。セルトリ細胞間の密着結合 は tight で高分子物質を通過させず，したがって分化 しつつある精細胞への栄養物質の移送はセルトリ細胞 を介して行われると推定される29).

細胞形質膜に存在する ATPase は細胞の代謝移送 と関連があるといわれている. 形質膜に ATPase 活性 が出現するのは生後13〜16日で，セルトリ細胞が成熟 型に, 精細胞が精子への分化を始める時期とよく一致 した。ささに全ての形質膜に ATPase 活性が出現する のではなく，七ルトリ細胞と接する部分にのみ活性が 認められた事は注目に値する。以上の所見はセルトリ 細胞が精巣の生後発育に扔いて精細胞の分化に関与
し, 特に栄養物質の移送も含め代謝移送と関連するこ とを示唆する。

\section{結 語}

精巣の生後発育にともなら精細管内の変化を電顕的 細胞化学的に検索し精細胞掞よびセルトリ細胞の形態 の変化と機能との関連を追究した. 生後 $1,2,3$, 4,5 週拉よび性的成熟した雄性ウィスター系ラット を用い，さらに形態変化のはげしい生後12ないし18日 については同腹のラット群を用い, 精細管内の酵素細 胞化学を行い電顕にて観察した。

ACPase 活性は生後 1 週から成熟精巣まで精細胞お よびセルトリ細胞のゴルジ装置とライソゾームに反応 を認めた。精子細胞では形成初期の先体内に活性を認 めた. 先体形成が進むと ACPase 活性は認められず, 何らかの機序で扣さえられたものと考学られた。

ATPase 活性は生後13日から出現し始め, 生後16日 では成熟したものと同様の部位に活性を呈した。セル トリ細胞と精細胞との細胞間隙に ATPase 活性を認 めたが精細胞同士の細胞間䣣には反応は陰性であっ た。活性の出現時期はセルトリ細胞が分化を始め血液 一精巣関門が完成する時期と精母細胞の出現時期と一 致した. 以上の結果は精巣の生後発育過程においてセ ルトリ細胞が精細胞の分化に関与し, 特に代謝移送と 関連することを示唆する。

本論文の要旨は第 1 回日本アンドロロジー学会（昭和 57 年 6 月17日 18日), 第 24 回日本組織細胞化学会総会 (昭和 58 年10月27日 28日), 第72回日本泌尿器科学会総会 (昭和 59 年 4 月 2 日〜 5 日) において発表した.

稿を終えるにあたり御指導, 御校閲を賜った恩師新島端 夫教授, 直接御指導いただいた横山正夫助教授(現虎の門病 院部長) に心から感謝致します. 東京大学泌尿器科教室員各 位の御劦力括よび福田覚氏 (東京大学医学部電顕室), 黒沢 園子氏 (東大分院泌尿器科) の技術的援助に感謝致します。

\section{文献}

1) Perey, B., Clermont, Y. and Leblond, C.P.: The wave of the seminiferous epithelium in the rat. Am. J. Anat., 108, 47-77, 1961.

2) Clermont, Y. and Perey, B.: Quantitative study of the cell population of the seminiferous tubules in immature rats. Am. J. Anat., 100, 241-267, 1957.

3) Clermont, Y.: Kinetics of spermatogenesis in mammals: Seminiferous epithelium cycle and spermatogonial renewal. Physiol. Rev., 52, 198-236, 1972.

4) De Kretser, D.M.: Ultrastructural features of 
human spermatogenesis. Z. Zellforsch., 98 : 477-505, 1969.

5) Susi, F.R., Leblond, C.P. and Clermont, Y.: Changes in the Golgi apparatus during spermiogenesis in the rat. Am. J. Anat., 130, 251-268, 1971.

6）永野俊雄：精子形成一とくに acrosome について 一. 代謝，14，2013-1019， 1977.

7) Ramos, A.S. and Dym, M.: Ultrastructural differentiation of rat Serotoli cells. Biol. Reprod., 21, 909-922, 1979.

8) Fawcett, D.W., Leak, L.V. and Heidger, P.M. : Electron microscopic observations on the structural components of the blood-testis barrier. J. Reprod. Fert. Suppl., 10, 105-122, 1970.

9）古屋聖児：奠丸機能の研究 (第 6 報) 七上血液一辡 丸(精巣) 関門の電顕的研究 (lanthanum-trace 法 拈よび Freeze-etching 法)。日泌尿会誌，66， 829-855, 1975.

10) Tindall, D.J., Vitale, R. and Means, A.R.: Androgen binding protein as a biochemical marker of formation of the blood-testis barrier. Endocrinology, 97, 636-648, 1975.

11) Furuya, S., Kumamoto, Y. and Sugiyama, S.: Fine structure and development of sertoli junctions in human testis. Arch. Androl., 1, 211-219, 1978.

12) Tice, L.W. and Barrnett, R.J.: The fine structural localization of some testicular phosphatases. Anat. Rec., 147, 43-64, 1963

13）横山正夫：精子形成過程の細胞化学. 臨泌，29, 849-852, 1975.

14) Novi, A.M. and Saba, P.: An electron microscopic study of the development of rat testis in the first 10 postnatal days. Z. Zellforsch., 86, 313-326, 1968.

15) Gomori, G.: In microscopic histochemistry, principles and practice, p. 189, Univ. Chicago Press, Chicago, 1952.

16) Wachstein, M. and Meisel, E.: Histochemistry of hepatic phosphatases at a physiologic pH. Am. J. Clin. Path., 27, 13-23, 1957.

17) Fawcett, D.W.: Ultrastructure and function of the Sertoli cell. Handbook of physiology, endocrinology (ed. by Hamilton, D.W. and Greep, R.O.), Vol. 5, p. 21, Williams and Wilkins, Ealtimore (1975).
18) Chang, J.P., Yokoyama, M., Brinkley, B.R. and Mayashara, H.: Electron microscopic cytochemical study of phosphatases during spermiogenesis in Chinese hamster. Biol. Reprod., 11, 601-610, 1974.

19) Barham, S.S., Berlin, J.D. and Brackeen, R.B.: The fine structural localization of testicular phosphatases in man: The control testis. Cell Tiss., 166, 497-510, 1976.

20) Chakraborty, J. and Nelson, L. : Organization and redistribution of adenosine triphosphatase during spermiogenesis in the mouse. Biol. Reprod., 10, 85-97, 1974.

21) Novikoff, A.B. and Goldfischer, S.: Nucleoside diphosphatase activity in the Golgi apparatus and its usefulness for cytological studies. Proc. Natl. Acad. Sci. U.S.A., 47, 802-810, 1961.

22) Allen, J.M. and Slater, J.J.: A cytochemical study of Golgi associated thiamine pyrophosphatase in the epididymis of the mouse. J. Histochem. Cytochem., 9, 418-423, 1961.

23）斉藤多久馬, 松下正也：ゴルジ装置の細胞化学. 生 体の科学, 31，12-21，1980.

24) Tang, X.M., Lalli, M.F. and Clermont, Y.: A cytochemical study of the Golgi apparatus of the spermatid during spermiogenesis in the rat. Am. J. Anat., 163, 283-294, 1982.

25）犬浦親善, 年森清隆：哺乳類の精子進入. 細胞, 12, 82-91, 1980.

26) Gravis, C.J., Yates, R.D. and Chen, I. : Light and electron microscopic localization of ATPase in normal and degenerating testes of Syrian hamsters. Am. j. Anat., 147, 419-431, 1976.

27) Chakraborty, J. and Nelson, L.: Adenylate cyclase in mouse testis. Biol. Reprod., 20, 131-139, 1979.

28) Josso, N., Picard, J.Y. and Tran, D.: The antimüllerian hormone. Rec. Progr. Horm. Res., Vol. 33, (ed. by Greep, R.O.), p. 117, Acad. Press (1977).

29) Russell, L.: Movement of spermatocytes from the basal to the adluminal compartment of the rat testis. Am. J. Anat., 148, 313-328, 1977.

（1986年10月 22 日受理, 特別掲載） 